\title{
Allergic manifestations and cutaneous histamine responses in patients with McCune Albright syndrome
}

\author{
Jill D Jacobson ${ }^{*}$, Angela L Turpin and Scott A Sands
}

\begin{abstract}
Background: McCune Albright syndrome (MAS) is a rare disorder characterized by precocious puberty, café-au-lait spots, and fibrous dysplasia. Its cause is an activating mutation in the GNAS gene, encoding a subunit of the stimulatory $G$ protein, $G_{s} a l p h a\left(G_{s} a\right)$. The action of any mediator that signals via $G_{s} a$ and cyclic AMP can be up regulated in MAS. We had observed gastritis, gastroesophageal reflux, and anaphylaxis in McCune Albright patients.
\end{abstract}

Objective: As histamine is known to signal via histamine $1(\mathrm{H} 1)$ and histamine $2(\mathrm{H} 2)$ receptors, which couple with stimulatory $\mathrm{G}$ proteins, we attempted to mechanistically link histamine responsiveness to the activating GNAS mutation. We hypothesized that responsiveness to histamine skin testing would differ between MAS patients and healthy controls.

Patients and methods: After obtaining informed consent, we performed a systematic review of histamine responsiveness and allergic manifestations in 11 MAS patients and 11 sex-matched, Tanner-stage matched controls. We performed skin prick testing, quantifying the orthogonal diameters of wheals and erythema. We also quantitated $\mathrm{G}$ protein mRNA expression.

Results: The peak wheal and flare responses to histamine were significantly higher in MAS patients compared to controls.

Conclusions: This study suggests that MAS patients may be at risk for exaggerated histamine responsiveness compared to unaffected controls.

Keywords: McCune Albright syndrome, Histamine responsiveness, Wheal and flare, Atopy, Anaphylaxis

\section{Introduction}

McCune-Albright syndrome (MAS) is a rare, intriguing, genetic disorder characterized by excessive activity of multiple hormones and other mediators that signal through cAMP. The original description by Fuller Albright included the triad of precocious puberty, café-aulait skin spots, and polyostotic fibrous dysplasia [1]. The causative mutation, identified in 1991, is a missense mutation in the GNAS gene, which leads to constitutive activation of the $G_{s} \alpha$ protein [2]. Mutations in the GNAS gene occur after conception, and the individual survives with mosaicism. As a result of this mosaicism, individuals with MAS display a wide spectrum of clinical

\footnotetext{
* Correspondence: jjacobson@cmh.edu

Section of Endocrinology, Children's Mercy Hospital, University of MissouriKansas City, School of Medicine, 2401 Gillham Road, Kansas, MO 64108, USA
}

severity and a wide range of endocrine manifestations. Purely endocrine features described in MAS include non-autoimmune hyperthyroidism, acromegaly, Cushing syndrome, hyperprolactinemia, and hyperparathyroidism. Bony problems include polyostotic fibrous dysplasia [3-7]. Several non-endocrine features more recently attributed to the molecular defect include platelet abnormalities, hepatobiliary disease, cardiac hypertrophy, and sudden or premature death [2,8-11]. The ongoing recognition of additional G protein-mediated signaling abnormalities in MAS may eventually lead to an increased number of supportive diagnostic criteria to aid in accurately diagnosing MAS.

We noted that a large number of our patients with MAS displayed a wide variety of atopic manifestations and hypersensitivities. Reactions ranged from asthma, 
drug and food sensitivities, contact dermatitis, and even anaphylaxis. In fact, over a period of three years, five MAS patients experienced anaphylaxis. We speculated that these observations were linked to the constitutive activation of the stimulatory $G$ protein, $G_{s} \alpha$.

Our initial observations of severe reactions to foods and inhalant allergies suggested classic IgE-mediated problems. The IgE receptor cross-linking process is mediated by tyrosine kinases, and is therefore not $G$ protein-mediated. However, we note that $G$ proteincoupled receptors (GPCRs) and cyclic AMP modulate numerous responses in neurological, immune, muscular, and vascular systems that contribute to allergic processes, asthma, and atopy. Classic examples of stimulatory $\mathrm{G}$ protein-coupled ligands that play crucial roles in atopy are histamine and leukotrienes [12,13]. Stimulatory $\mathrm{G}$ protein-coupled ligands such as acetylcholine and epinephrine play crucial roles in bronchoconstriction $[14,15]$. Examples of stimulatory $G$ protein-coupled ligands that play crucial roles in vasomotor function are substance P and catecholamines [16,17].

We noted that two of our MAS patients suffered from severe gastritis and gastroesophageal reflux. Such findings are suggestive of $\mathrm{H} 2$ receptor activation. We speculated that some of our observations of hypersensitivities in MAS patients might be linked to exaggerated histaminic signaling augmented by the constitutive activity of $\mathrm{G}_{\mathrm{s}} \alpha$ protein. However, of the four major histamine receptors, $\mathrm{H} 1$ through $\mathrm{H} 4$, only the $\mathrm{H} 2$ receptor is classically described as coupling to $G_{s} \alpha$ and cAMP [18-20]. Activation of this $\mathrm{H} 2$ receptor is traditionally not associated with allergy, but rather with gastric histaminic activity. In contrast, the histamine 1 (H1) receptor, which is traditionally associated with allergy and urticaria, is coupled to a separate stimulatory $G$ protein of the $G_{q} \alpha$ pathway [20]. H3 and H4 receptors exert actions via inhibitory $\mathrm{G}$ proteins, which generally mediate cAMP inhibition [21,22].

Many lines of evidence suggest "cross talk" between $\mathrm{G}_{\mathrm{s}} \alpha$ pathway (which traditionally signals via cAMP) and $\mathrm{G}_{\mathrm{q} / 11} \alpha$ pathway (which traditionally signals via inositol phosphates) in the signaling of guanine nucleotide binding $(G)$ protein coupled receptors (GPCRs), including histamine receptors [13,20,23-27]. Constitutive coexpression of a 5- hydroxytryptamine receptor with the $\mathrm{G}_{\mathrm{q} / 11} \alpha$ coupled histamine 1 receptor results in increased agonist-independent signaling, which can be augmented by agonist activation of various other $\mathrm{G}$ protein coupled receptors, including muscarinic and adenosine receptors [28].

Previous studies have demonstrated that skin reactivity to histamine testing varies with the menstrual cycle in both healthy and atopic women, with heightened reactivity seen in midcyle, corresponding to peak estrogen and gonadotropin stimulation [29,30]. We have previously reported that exposure to either estrogen or to gonadotropin-releasing hormone $(\mathrm{GnRH})$ stimulates $\mathrm{G}_{\mathrm{q} / 11} \alpha$ mRNA expression in immune cells in mice $[31,32]$. Because patients with MAS exhibit post-receptor activation of $\mathrm{GnRH}, \mathrm{LH}$, and FSH receptors, we speculated that other $G$ protein signaling pathways might be up regulated in MAS.

Herein, we hypothesized that patients with MAS would demonstrate evidence of increased $\mathrm{H} 1$ and/or $\mathrm{H} 2$ activity. We measured wheal and flare skin responses to histamine compared to Tanner Stage matched, sexmatched, unaffected controls. We also sought evidence for increased allergic phenomena in MAS patients by systematically reviewing their allergic histories. We quantified expression of $G_{s} \alpha$ mRNA and $G_{q} \alpha$ mRNA and protein in peripheral blood mononuclear cells (PBMCs). We also sought a correlation between histamine responsiveness and activation of the hypothalamicpituitary-gonadal axis, as measured by Tanner staging.

\section{Patients and methods Study design}

This is a single-center, prospective, nonrandomized study comparing patients with the clinical diagnosis of MAS to Tanner stage-matched, sex-matched healthy controls. The study and all procedures were approved by the Institutional Review Board and performed in compliance with the World Medical Association Declaration of Helsinki regarding the ethical conduct of research. All participants were evaluated over a 3 year period beginning in August of 2004. Two separate consent forms were utilized for $\mathrm{G}$ protein measurement, Tanner staging, allergic histories, IgE measurements, and skin testing. Histories of allergic histories and medical therapies for allergies were obtained retrospectively. Menstrual histories were taken in female participants. Pubertal development was assessed by Tanner stage of pubic hair and breast development (girls) and testicular volume (boys) [33].

\section{MAS participants}

We identified 12 MAS patients who were regularly followed in our endocrinology clinic. The diagnosis was diagnosed based on clinical criteria. Patients were required to exhibit at least two major features of MAS (precocious puberty, polyostotic fibrous dysplasia, and café-au-lait spots). All patients underwent endocrine evaluations including thyroid function testing at least annually. Only one female patient with MAS exhibited regular menstrual cycles. After obtaining informed consent, we obtained information about adverse drug and food reactions retrospectively from the medical record charts. One out of the 12 patients was unable to 
participate in the skin testing for geographic reasons. This patient had a history of anaphylaxis necessitating epinephrine administration after receiving radiographic contrast. The clinical characteristics of the 11 participating patients with MAS are shown in Table 1.

\section{Control participants}

Healthy control children with no increased risk for allergies were recruited by an institutional electronic advertisement. An allergy questionnaire was administered to all patients and controls. Allergic manifestations in controls were similar to that seen in the general population. One out of eleven (9\%) controls reported seasonal rhinitis. No other allergic phenomena were reported in control participants.

Controls were Tanner Stage-matched to MAS patients. Because MAS patients exhibited precocious puberty, we matched patients and controls by Tanner Stage rather than by age. In order to match by age, we would have had to use controls with precocious puberty in order to age match.
Eleven Tanner stage-matched, sex-matched control patients underwent skin testing. Two of these control participants had undergone Tanner staging for clinical care purposes. The Tanner stage(s) of these individuals was therefore not recorded in the research record. Two female control participants had already achieved menstrual regularity. A second set of 11 sex-matched, Tanner stagematched control participants did not undergo skin testing, but were recruited specifically for $\mathrm{G}$ protein measurement, in order to increase the sample size of controls.

\section{Power analysis}

Pilot data in mice demonstrated that early exposure to estradiol leads to a three-fold increase in expression of mRNA for stimulatory $G$ proteins in various tissues. As MAS patients exhibit early activation of the HPG axis, we speculated that similar differences might be seen in humans. A power analysis revealed that an $\mathrm{n}$ of 8 would yield an $80 \%$ power to detect similar differences in G protein mRNA expression. Thus our patient population

Table 1 Clinical manifestations of patients with MAS

\begin{tabular}{|c|c|c|c|c|c|c|c|c|c|c|c|}
\hline $\begin{array}{l}\mathrm{Pt} \\
\#\end{array}$ & $\begin{array}{l}\text { Age } \\
(Y r)\end{array}$ & Sex & $\begin{array}{l}\text { Tanner } \\
\text { stage }\end{array}$ & $\begin{array}{l}\text { Polyostotic } \\
\text { fibrous } \\
\text { dysplasia }\end{array}$ & $\begin{array}{l}\text { Characteristic } \\
\text { café-au- lait } \\
\text { spots }\end{array}$ & $\begin{array}{l}\text { Gonadotropin } \\
\text { independent } \\
\text { precocious } \\
\text { puberty }\end{array}$ & $\begin{array}{l}\text { Non } \\
\text { autoimmune } \\
\text { thyroid } \\
\text { disease }\end{array}$ & $\begin{array}{l}\text { \# MAS } \\
\text { features }\end{array}$ & $\begin{array}{l}\text { Max } \\
\text { flare } \\
(\mathrm{mm})\end{array}$ & $\begin{array}{l}\text { Max } \\
\text { wheal } \\
(\mathrm{mm})\end{array}$ & $\begin{array}{l}\text { Manifestations of atopy/ } \\
\text { hypersensitivity }\end{array}$ \\
\hline 1 & 17 & M & 5 & Yes & Yes & Yes & Yes & 4 & 107 & 21 & $\begin{array}{l}\text { anaphylaxis (latex), drug } \\
\text { allergies (morphine, } \\
\text { penicillin), asthma H. Pylori } \\
\text { negative ulcer } \\
\text { Other sensitivities (topical } \\
\text { benzocaine) }\end{array}$ \\
\hline 2 & 15 & $\mathrm{~F}$ & 5 & No & Yes & Yes & No & 2 & 156 & 18 & $\begin{array}{l}\text { anaphylaxis (strawberries), } \\
\text { drug allergies (ibuprofen, } \\
\text { tylenol), multiple food } \\
\text { allergies, chronic gastritis }\end{array}$ \\
\hline 3 & 12 & $\mathrm{~F}$ & 3 & Yes & Yes & Yes & No & 3 & 105 & 11 & $\begin{array}{l}\text { anaphylaxis (cashews), atopic } \\
\text { dermatititis,drug allergy } \\
\text { (erythromycin), } \\
\text { Other sensitivities (nickel, } \\
\text { surgical tape) }\end{array}$ \\
\hline 4 & 13 & $\mathrm{~F}$ & 3 & Yes & Yes & Yes & No & 3 & 98 & 7 & anaphylaxis (penicillin) \\
\hline 5 & 13 & $\mathrm{~F}$ & 3 & Yes & Yes & Yes & No & 3 & 100 & 17 & $\begin{array}{l}\text { positive skin testing } \\
\text { (ragweed, dust mites), } \\
\text { asthma, atopic dermatitis, } \\
\text { chronic urticaria }\end{array}$ \\
\hline 6 & 10 & $\mathrm{~F}$ & 1 & Yes & Yes & No & Yes & 3 & 70 & 12 & $\begin{array}{l}\text { multiple drug allergies } \\
\text { (methimazole, } \\
\text { propylthiouracil) }\end{array}$ \\
\hline 7 & 8 & $\mathrm{~F}$ & 3 & Yes & Yes & Yes & No & 3 & 112 & 10 & $\begin{array}{l}\text { drug allergy (letrozole) } \\
\text { Other sensitivities (gluten, } \\
\text { surgical tape), chronic urticaria }\end{array}$ \\
\hline 8 & 17 & $F$ & 5 & Yes & Yes & Yes & No & 3 & 98 & 14 & asthma, latex allergy \\
\hline 9 & 7 & $\mathrm{~F}$ & 2 & No & Yes & Yes & No & 2 & 75 & 18 & $\begin{array}{l}\text { atopic dermatitis, seasonal } \\
\text { rhinitis, chronic urticaria }\end{array}$ \\
\hline 10 & 7 & $F$ & 2 & No & Yes & Yes & No & 2 & 92 & 14 & asthma, seasonal rhinitis \\
\hline 11 & 16 & $M$ & 5 & Yes & Yes & No & No & 2 & 135 & 17 & none \\
\hline
\end{tabular}


of 11 would offer adequate power to detect similar differences in $\mathrm{G}$ protein mRNA expression.

\section{Skin testing}

If patients had received antihistamines or glucocorticoids in the two weeks prior to IRB consent, they were excluded and consented when they were no longer requiring these medications. Blood was drawn for $\operatorname{IgE}$ measurement. Participants then underwent standard allergy testing using the commercially available Greer Skin testing system as a prick test device (Greer Labs, Lenoir, N.C.). Histamine (Hollister-Stier Laboratories, Spokane, WA) was used at a concentration of $6 \mathrm{mg} / \mathrm{ml}$. Codeine (20 mg/ml; Hospira, Inc., Lake Forest, IL) was used as a control whose actions are mediated by IgE independent histamine release [34]. It signals via both stimulatory and inhibitory $G$ proteins [35]. Normal saline was also used as a negative control. Tests were spaced at least $3 \mathrm{~cm}$ apart to avoid difficulty with interpretation. Two standard sites were used for skin testing for all participants, the back and the arm. When cutaneous café-aulait spots were present on standard sites on the back or arm $(n=4)$, the solutions were also applied to the contralateral unaffected skin site. Data from the unaffected skin sites only were used in comparisons between MAS patients and controls. All testing was performed by a single trained allergy nurse. Wheal and flare responses were measured at 7 and 20 minutes after the skin tests were administered. The wheal and flare responses were outlined in ink, and the image transferred to hypoallergenic transparent tape to create a permanent record. Tape was placed in a permanent record book for measurement. Thus, measurement was performed with blindness to the skin pigmentation. The longest diameter of erythema was measured. A line was drawn perpendicular to the longest diameter of erythema (the orthogonal diameter) and also measured. These two lengths were arithmetically summed, according to a standard, published protocol, as delineated in Figure 1 [36]. The same procedure was used to quantitate the wheal

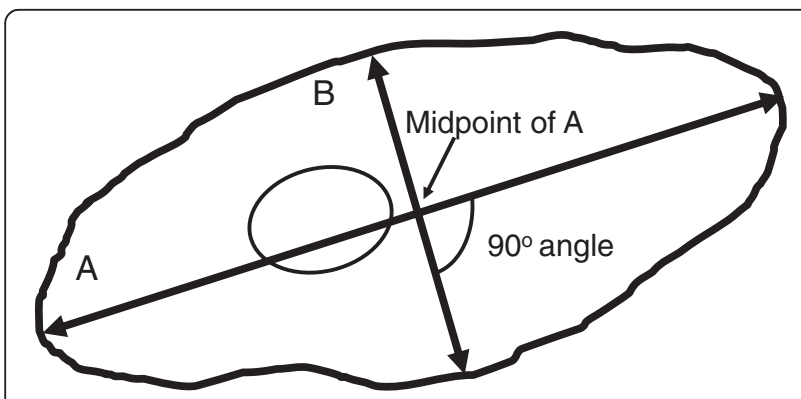

Figure 1 Diagram depicting the method of measurement of the sums of wheal and flare ( $\Sigma$ of flare) responses to histamine skin testing. response to histamine, which was, in all cases, smaller than the erythema measurement. The intra-individual coefficient of variation of this histamine skin prick testing is reported to be $20 \%$ [37]. In the current study the coefficient of variation in flare response to histamine was $32 \%$ in controls. Peak reactions, irrespective of anatomical location, and site-specific wheal and flare responses were compared between MAS patients and controls. Epinephrine pens were available at the bedside during skin testing.

\section{Genetic testing}

The three study subjects who displayed anaphylactic reactions underwent genetic testing for mutations in GNAS in peripheral blood. Mutational analysis of the Arg 201 locus of GNAS was performed using sitespecific polymerase chain reaction (PCR), restriction digestion and DNA sequencing.

\section{PBMC isolation}

PBMCs were isolated from heparinized blood using Histopaque 1077 (Sigma-Aldrich, St. Louis, MO). Cells were pelleted, and resuspended in Buffer RLT Plus from the RNeasy ${ }^{\circledR}$ Mini Plus Kit (QIAgen, Valencia, CA) and stored at $-80^{\circ} \mathrm{C}$ until further processing.

\section{RNA isolation and quantitation}

Samples were thawed, vortexed, and placed in QIAshredder columns and processed according to the manufacturer's directions. RNA was examined by spectrophotometry and quantitated using the Ribogreen assay (Invitrogen, Carlsbad, CA). Ribogreen reagent was added to samples and standards, and samples were read on a Bio-Tek FL 800 fluorescent plate reader. RNA was diluted in nuclease-free water to a final concentration of $150 \mathrm{ng} / \mathrm{ml}$ cDNA. RNA quality was assessed by spectrophotometry and by the cycle number for the housekeeping gene, GAPDH.

\section{Reverse transcription and one-step real time PCR}

DNA was digested using DNase 1, and residual DNase activity was quenched with EDTA. Reverse transcription was then performed using the SuperScript II Reverse Transcription Kit (Invitrogen, Carlsbad, CA) according to the manufacturer's instructions. One-step real-time RT-PCR was performed using the SYBR Green PCR kit (Bio-Rad, Hercules, CA). G protein sequences were obtained from the Gene Bank database and the following primers were constructed Using the GenBank sequence for GNAS NM_000516: $\mathrm{G}_{\mathrm{s}} \alpha$ sense: $5^{\prime}-\mathrm{TCT}$ ACC GGG CCA CGC ACC GC-3'; $\mathrm{G}_{\mathrm{s}} \alpha$ antisense: 5'-GCA GGA TCC TCA TCT GCT TC-3'. We utilized the human GNAQ sequence NM_002072 to create the following primers: $\mathrm{G}_{\mathrm{q}} \alpha$ sense: 5'-GAT GTT CGT GGA CCT GAA 
CC-3'; $\mathrm{G}_{\mathrm{q}} \alpha$ antisense: 5'-CAA CTG GAC GAT GGT GTC CT-3'. BLAST searches were performed using the National Center for Biotechnology Information's BLAST WWW Server. Commercially available primers were used for the housekeeping gene, GAPDH (Clontech, Mountain View, CA). The following parameters were used for the RT-PCR program for all genes: $95^{\circ} \mathrm{C} 3 \mathrm{~min}$; 35 cycles of $95^{\circ} \mathrm{C} 20 \mathrm{sec}, 56^{\circ} \mathrm{C} 20 \mathrm{sec}, 72^{\circ} \mathrm{C}$ for $20 \mathrm{sec}$; $95^{\circ} \mathrm{C} 1 \mathrm{~min}$; and $55^{\circ} \mathrm{C} 7 \mathrm{~min}$. Data were calculated as the delta $\mathrm{Ct}$ ratio of the gene of interest compared to the delta $\mathrm{Ct}$ of the housekeeping gene (GAPDH). That ratio was also normalized as a percent of an internal standard control sample, prepared from a pool of PBMCs from healthy adult males and females.

\section{Protein quantitation}

Protein concentrations were determined by the Bradford method utilizing a Coomassie protein assay kit from Pierce Biotechnology (Rockland, IL). A standard curve using bovine serum albumin was established from 0 to $2000 \mu \mathrm{g} / \mathrm{ml}$. Sample $(5 \mu \mathrm{l})$ was added to 96 well plates in duplicate. Coomassie reagent $(250 \mu \mathrm{l})$ was added to each well and incubated for 10 minutes at RT. The absorbance was measured at $595 \mathrm{~nm}$ on a Power WaveX plate reader (Bio-Tek, Winooksi, VT).

\section{Immunoblot analysis for membrane-associated proteins}

Total membrane protein $(200 \mu \mathrm{g}$ per well) was electrophoresed in $12 \%$ Tris- $\mathrm{HCl}$ gels and transferred to nitrocellulose membranes (Biorad, Hercules, CA) by electroblotting. Membranes were blocked in Trisbuffered saline with .1\% Tween-20 (TBST) and 5\% non fat dry milk, then incubated overnight with affinitypurified rabbit polyclonal IgG antibodies specific to each G protein (Santa Cruz Biotechnology, Santa Cruz, CA). The $G_{q} \alpha$ antibody does not cross- react with the related $G$ protein subunit, $G_{11} \alpha$. Membranes were incubated for $1 \mathrm{~h}$ in TBST with horseradish peroxidase conjugated $2^{\circ}$ antibodies (Jackson Immunoresearch, West Grove, PA). Bands were visualized by chemiluminescence via western blot luminal reagent (Santa Cruz Biotechnology, Santa Cruz, CA) by exposure to Classic BX autoradiography film (MidSci, St. Louis, MO). The membranes were then stripped with western blot stripping buffer (Fisher Scientific, Hanover Park, IL) for $30 \mathrm{~min}$ at $37^{\circ} \mathrm{C}$ and reprobed for actin protein as an internal control, using a monoclonal primary antibody (MP Biomedicals, Santa Ana, CA). Bands were quantitated using densitometry and ImageQuant 5.2 software (Molecular Dynamics, Foster City, CA).

\section{Sequencing}

$G_{s} \alpha$ and $G_{q} \alpha$ PCR fragments were treated with ExoSAPIT (USB, Cleveland, $\mathrm{OH}$ ) and subsequently sequenced using BigDye terminator v3.1 cycle sequencing chemistry and a 3730 capillary DNA analyzer (Applied Biosystems, Foster City, CA).

\section{Statistics}

Differences in skin testing results between groups were assessed using 95\% confidence intervals. G protein mRNA expression and IgE levels were compared by Wilcoxon rank sum tests. Because data were not normally distributed, Spearman correlation coefficients were determined comparing Tanner stage and peak histamine responses and between $G$ protein $\mathrm{mRNA}$ and protein measurements.

\section{Results}

Atopic manifestations and hypersensitivities

Retrospective analysis revealed that ten out of 11 (90.9\%) patients with MAS in this study displayed atopy and hypersensitivities encompassing a wide variety of reactions (Table 1). Allergic phenomena suggestive of $\mathrm{H} 1$ receptor activation included seasonal rhinitis, eczema, asthma, food allergies, drug reactions, latex allergies, and anaphylaxis. Activation of the $\mathrm{H} 2$ receptor was suggested by chronic gastritis, $H$. pylori negative ulcers, and gastroesophageal reflux noted in two patients. Type IV reactions, including severe bullous reactions to surgical tape occurred in two individuals. Anaphylaxis necessitating epinephrine administration had occurred in four of the 11 patients in the current study. Two of these patients experienced anaphylaxis after food ingestions, one after skin contact with latex, and one after receiving penicillin.

\section{Flare responses to histamine}

Patients with MAS displayed significantly more vigorous flare responses to histamine when comparing the same anatomical site to that of controls. The sum of the skin flare response to histamine on the back was $92.7 \pm$ $20.0 \mathrm{~mm}$ in MAS patients compared to $66.1 \pm 12.4 \mathrm{~mm}$ in controls (mean \pm S.D.) (95\% confidence interval (CI) 11.8 to $41.4 ; \mathrm{p}=0.0013$ : Figure 2 ).

Similar flare responses were seen using the arm, although more variability was seen: $92.4 \pm 30.2 \mathrm{~mm}$ in MAS patients compared to $68.3 \pm 25.7 \mathrm{~mm}$ in controls (95\% CI -0.8 to $49.0 ; \mathrm{p}=0.057$ ).

The peak flare response to histamine irrespective of anatomical location was also significantly higher in patients with MAS compared to controls [104.4 $\pm 24.4 \mathrm{~mm}$ in MAS patients compared to $76.4 \pm 12.9 \mathrm{~mm}$ in controls (95\% CI 10.6 to $45.4 ; \mathrm{p}=0.003)$ ].

\section{Wheal responses to histamine}

Patients with MAS also displayed significantly more vigorous wheal responses to histamine compared to 


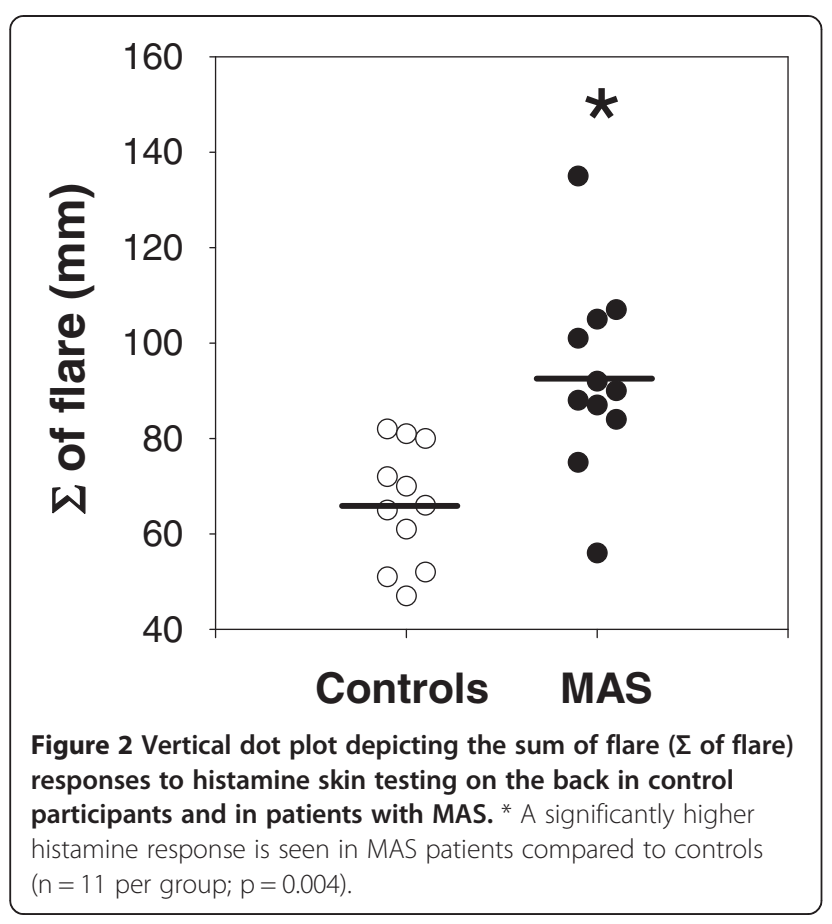

controls in the back only. The sum of the mean skin wheal response to histamine on the back was $12.8 \pm$ $3.7 \mathrm{~mm}$ in MAS patients compared to $9.3 \pm 3.1 \mathrm{~mm}$ in controls (95\% CI 0.46 to 6.54; $\mathrm{p}=0.026$; Figure 3 ).

No statistically significant differences in wheal responses in the arm were seen: $13.7 \pm 3.8 \mathrm{~mm}$ in MAS patients compared to $13.1 \pm 5.3 \mathrm{~mm}$ in controls $(95 \%$ CI

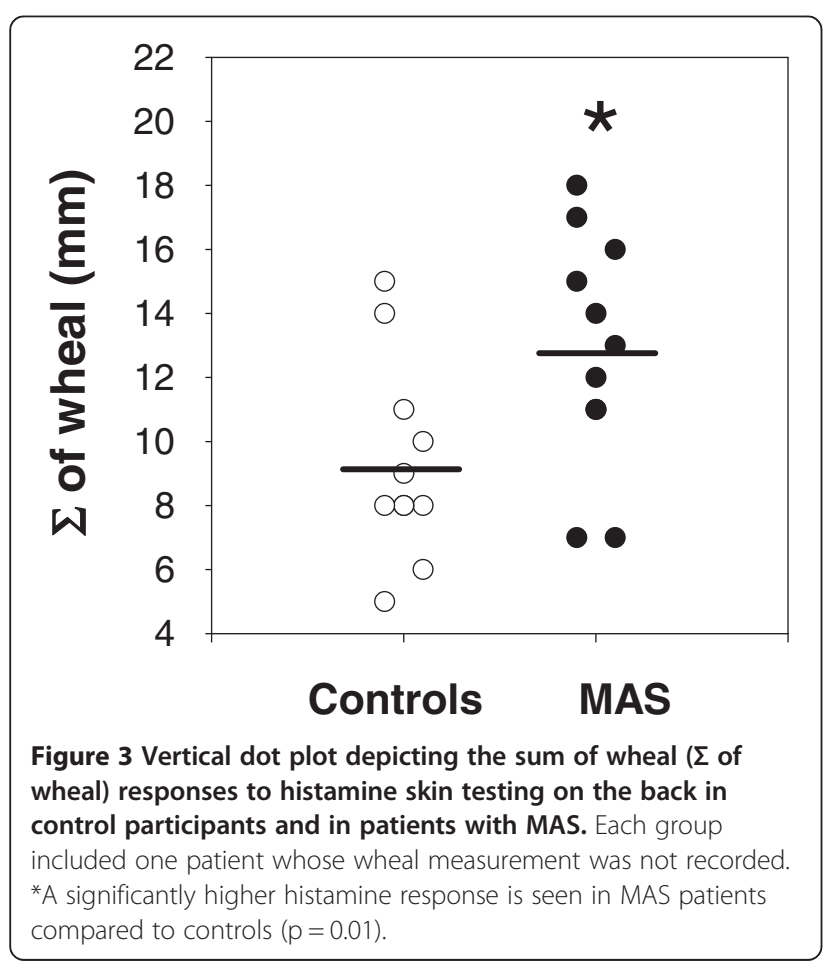

-3.50 to $4.70 ; p=0.76$ ). The differences in the peak wheal response to histamine irrespective of anatomical location between patients and controls also did not reach statistical significance $14.5 \pm 4.1 \mathrm{~mm}$ in MAS patients compared to $13.6 \pm 5.4 \mathrm{~mm}$ in controls (95\% CI -3.364 to $5.164 ; \mathrm{p}=0.66$ ).

\section{Responses to codeine}

No differences were seen in wheal or flare responses to codeine. The sum of the skin flare response to codeine on the back was $37.8 \pm 39.3 \mathrm{~mm}$ in MAS patients compared to $24.7 \pm 26.3 \mathrm{~mm}$ in controls $(95 \% \mathrm{CI}-16.6$ to $42.8 ; \mathrm{p}=0.36$ ). The sum of the skin wheal response to codeine on the back was $8.8 \pm 5.9 \mathrm{~mm}$ in MAS patients compared to $6.3 \pm 2.7 \mathrm{~mm}$ in controls (95\% CI -1.7 to $6.7 ; \mathrm{p}=0.22$ ).

\section{G protein mRNA expression}

Sufficient quantities and quality of mRNA for PCR analysis were obtained from 9 to11 participants per group. No statistically significant differences between $G_{s} \alpha$ mRNA levels were seen in patients versus controls. In contrast, MAS patients displayed significantly elevated median levels of $G_{q} \alpha$ mRNA compared to controls (Figure 4; $\mathrm{n}=9$-11 per group; $\mathrm{p}=0.039$ ). This difference was confirmed using the larger data which included two sex-matched, Tanner stage matched control participants for every patient with MAS. The median $\mathrm{G}_{\mathrm{q}} \alpha$ mRNA level in controls was 386.38 versus 735.8 in MAS ( $=0.036$; data not shown).

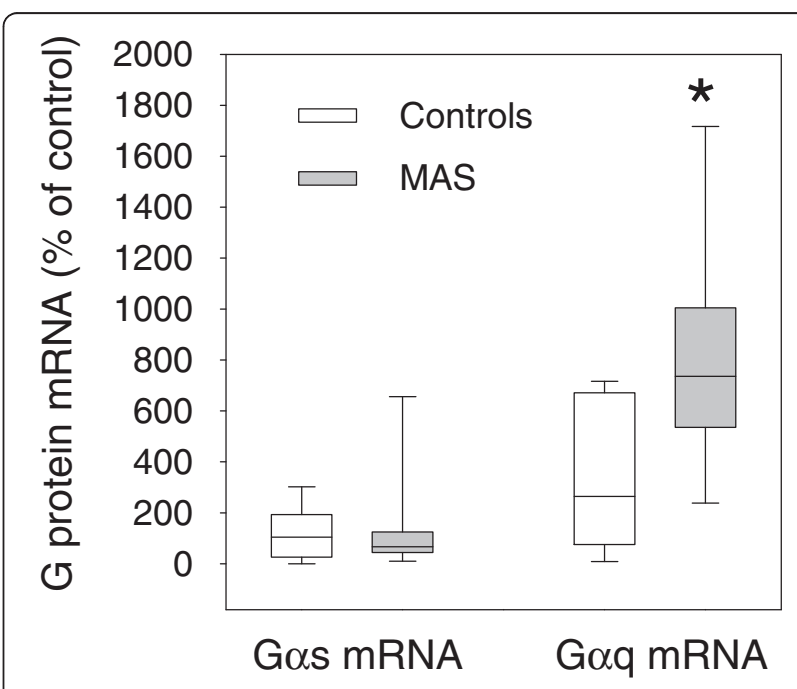

Figure 4 Whisker plot of Gas mRNA and Gaq mRNA in controls versus MAS participants. Sufficient quantities and quality of mRNA were available on 9 to 11 participants per group. Although no differences are seen in Gas mRNA, * Gaq mRNA is significantly higher in MAS patients compared to controls $(p=0.039)$. The solid lines within the boxes represent median values. 


\section{G protein expression}

Sufficient quantities of protein for immunoblot analysis were obtained from nine participants per group. No statistically significant differences between $G_{s} \alpha$ or $G_{q} \alpha$ protein levels were seen in patients versus controls. A direct positive correlation was seen between $G_{\mathrm{q}} \alpha$ mRNA and $\mathrm{G}_{\mathrm{q}} \alpha$ proteins, but in control participants only $(\mathrm{rho}=$ $0.61 ; \mathrm{p}=0.03$; data not shown).

\section{Effect of café-au-lait spots}

No significant differences in wheal or flare responses to histamine, codeine, or saline were observed between the affected skin lesions to the contralateral unaffected skin site.

\section{Effect of severity of disease}

A regression analysis was performed comparing the number of traditional manifestations of MAS and peak flare in response to histamine. No correlation was seen, Spearman $(r)=-0.22 ; \mathrm{p}=0.477$.

\section{Effect of puberty}

A regression analysis comparing Tanner stage to the maximum histamine flare response irrespective of anatomical site showed significant direct positive correlations in both patients with MAS and in control participants. The Spearman correlation coefficient $(r)$ for MAS patients was 0.67; $p=0.02$. The Spearman $r$ for control participants was 0.64; $\mathrm{p}=0.03$; Figure 5 .

\section{IgE levels}

The mean IgE level in MAS patients was $653.1 \pm 1195.9$ $\mathrm{kU} / \mathrm{L}$ and $81.0 \pm 100.7 \mathrm{kU} / \mathrm{L}$ in controls. This difference did not reach statistical significance $(p=0.149)$.

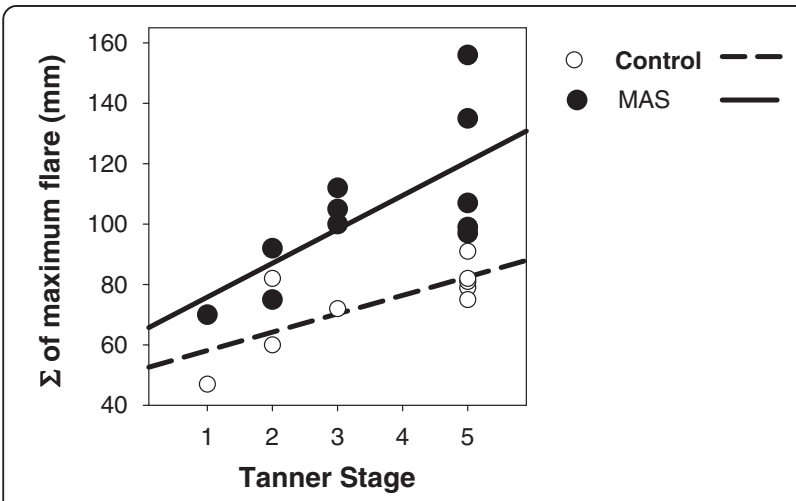

Figure 5 Regression analysis demonstrating a direct, positive correlation between Tanner stage and the maximum sum of flare responses to histamine skin testing irrespective of anatomical site in patients with MAS $(n=11$; Spearman $r=0.67$; $p=0.02)$ and in healthy control participants $(n=9$; Spearman $r=0.64 ; p=0.03$ ).

\section{Genetic testing}

An Arg 201 mutation was detected in exon 8 in one of the three participants who underwent genetic testing after experiencing anaphylaxis. This is patient \#1, the most severely affected patient.

\section{Discussion}

We have identified a high rate of allergic phenomena and hypersensitivities in patients with MAS compared to controls. In the current study, ninety-one percent of patients exhibited allergic phenomena ranging in severity from medication allergies to anaphylaxis. This is the first such report of atopy in McCune Albright syndrome in the medical literature. These observations ranged from classic IgE mediated phenomena to classic Type IV hypersensitivity reactions such as contact dermatitis. The wide range of sensitivities seen may result from the fact that numerous neurotransmitters, chemokines, cytokines, leukotrienes, and vasoactive peptides exert their actions via stimulatory $G$ proteins, and predominantly via $G_{s} \alpha$.

We have also observed a heightened wheal and flare response to histamine skin testing in MAS patients. This observation may be considered surprising, as the molecular defect in MAS is a constitutive activation of $G_{s} \alpha$. Of all the histamine receptors, only $\mathrm{H} 2$ receptors signal via $G_{s} \alpha$. Although $H 2$ receptors are important in gastric acid secretion, they are thought to play a minor role in allergy and in urticaria. In those conditions, H1 receptors, which signal via $G_{q} \alpha$, are thought to play predominant roles.

We did not observe a statistical increase in wheal and flare responsiveness to codeine in MAS patients compared to controls. If the heightened wheal and flare responses could be attributed solely to effects of histamine, one might have expected similar results with codeine as with histamine, as codeine induces histamine release by mast cells [34]. The differences in responsiveness to codeine and histamine could relate to the fact that codeine exerts its actions via an IgE independent mechanism and via classic opioid receptors, which signal via $G_{\mathrm{q}} \alpha$ as well as via inhibitory $G$ proteins [35]. Codeine has been shown to exert additional actions in mast cells, including cytokine and chemokine release [35].

It is possible that the exaggerated histamine responses observed herein may have been amplified by gonadal hormones. The hypothalamic pituitary gonadal axis is known to be activated in female patients with MAS with sexual precocity. In support of this hypothesis, previous studies show a variation in histamine skin testing responses during the menstrual cycle and a positive correlation between serum estradiol and LH levels in females $[29,30]$. We did not measure gonadotropins of estradiol in our population, as these are dramatically altered by 
the stage of the menstrual cycle. Only one of our patients exhibited regular menstrual cycles. We used Tanner staging as a surrogate for chronic hormone exposure. Although our numbers are small, we have demonstrated statistically significant positive correlations between histamine responses and Tanner stage both in our MAS population and in healthy control participants.

We speculate that the aberrant activation of the hypothalamic pituitary gonadal axis in MAS may contribute to the activation of $G_{q} \alpha$ and the $H 1$ receptor pathways. In fact, we have previously demonstrated that exposure to estradiol or GnRH leads to a transcriptional upregulation of $\mathrm{G}_{\mathrm{q} / 11} \alpha$ [32]. Herein, we observed an upregulation in $\mathrm{G}_{\mathrm{q}} \alpha$ mRNA expression in MAS participants compared to controls and confirmed these finding in a larger sample size. It is perhaps not surprising that we did not observe a transcriptional upregulation in $G_{s} \alpha$ in MAS patients. This may relate to the mosaicism in this condition. In the presence of an activating mutation of the GNAS gene in MAS, further transcriptional upregulation of GNAS would not seem to be adaptive.

The constitutive activation of a stimulatory $\mathrm{G}$ protein in the clinical condition of MAS may offer important insights into mechanisms in histamine signaling. Constitutive activity of one GPCR in the absence of ligand binding may have important implications for histamine "cross talk." It is interesting to note that antihistamines are actually inverse agonists, meaning that they can reduce histamine receptor constitutive activity in the absence of binding of any histaminic ligand. Our results support the possibility that the constitutive activation of one $G$ protein coupled histamine receptor, namely $G_{s} \alpha$, may offer a permissive effect on $G_{\mathrm{q}} \alpha$ activity. Numerous in vitro studies examining other agonists that signal through GPCRs have shown that expression of constitutively active stimulatory $\mathrm{G}$ protein coupled receptors allows for enhanced signaling of other co-expressed $G$ protein receptors [23-25]. In fact, synergism has been demonstrated between $\mathrm{H} 1$ and $\mathrm{H} 2$ receptors, with cross talk between the $G_{q} \alpha / P K C$ and the $G_{s} \alpha / P K A$ pathways [13,20,27].

One proposed mechanism for these observations is that both $\mathrm{H} 1$ and $\mathrm{H} 2$ agonists compete for clearance by the same cytochrome P450 isoenzyme [38]. This mechanism could not explain the numerous reports of in vitro cross talk between $\mathrm{H} 1$ and $\mathrm{H} 2$ receptors, however $[13,27]$. Again, our data are consistent with the concept that the constitutive activation of $\mathrm{G}_{\mathrm{s}} \alpha$ may offer a permissive effect on $G_{q} \alpha$-coupled receptors.

Human clinical studies also support the concept of "cross talk" between $\mathrm{H} 1$ and $\mathrm{H} 2$ action in dermatologic manifestations: $\mathrm{H} 2$ blockers have been noted to be clinically beneficial in the management of chronic urticaria and dermographism $[26,39,40]$. A recent meta-analysis showed that a combination of ranitidine with diphenhydramine was slightly more effective at improving the resolution of urticaria than diphenhydramine administered alone [41]. However, the authors concluded that the review did not allow confident decision-making about the use of $\mathrm{H} 2$ receptor antagonists for urticaria [41].

A limitation of the study was that it is difficult to positively confirm the diagnosis in MAS. Genetic testing by PCR methods currently is available, but it detects the mutation in peripheral blood in only an estimated $40 \%$ of individuals because of the mosaicism of this condition. The detection rate can be increased significantly when cellular bony tissue is available. The diagnosis of McCune Albright syndrome remains a clinical one, which necessitates the presence of at least two features of the classic triad [11].

Another limitation of the study was that the study numbers are small. If increased atopy or excessive histamine responsiveness can be confirmed in a larger group of patients, especially in patients with molecularly confirmed MAS, inclusion of allergic phenomena among the supporting diagnostic criteria of MAS may be warranted. Additional supportive diagnostic criteria would be extremely clinically useful in the management of patients with MAS. A high frequency of formes frustes variants exists in this condition. For example, patients with isolated monostotic and polyostotic fibrous dysplasia have been shown to display activating mutations in GNAS without the full spectrum of McCune Albright syndrome [42-44]. Variable tissue expression, mosaicism, and non-confirmatory genetic testing in this condition all lead to underdiagnosis of MAS.

Another limitation of the study was the lack of a dose-response curve. If MAS patients indeed possess exaggerated wheal and flare responses to both histamine and to saline compared to controls, as our data suggest, perhaps the differences between MAS patients and controls could have been further amplified at much lower doses of histamine.

The current study raises the possibility that in vivo or in vitro testing for heightened responsiveness to other G protein-linked endocrine or non-endocrine mediators could eventually lead to improved clinical diagnostic testing for MAS.

The current findings, which have implications in both the diagnosis and management of MAS, indicate a need for confirmatory studies in a larger series of patients with genetically confirmed MAS.

\section{Competing interests}

There is no conflict of interest that could be perceived as prejudicing the impartiality of the research reported. 


\section{Authors' contributions}

JDJ and ALT collected and recorded data. SAS performed most of the molecular studies. JDJ and SAS analyzed data. JDJ, SAS, and ALT wrote the manuscript. All authors read and approved the final manuscript.

\section{Acknowledgments}

We are indebted to Pamela S. Ryan, L.P.N., AE-C (certified asthma educator), for performing all skin testing. We are indebted to Andrea Gaedigk, Ph.D., for sequencing the $P C R$ products.

\section{Funding}

This work was supported by the Katherine Berry Richardson Foundation, an internal funding mechanism for Children's Mercy Hospitals and Clinics.

Received: 20 September 2012 Accepted: 16 April 2013

Published: 1 May 2013

\section{References}

1. Albright F, Butler A, Hampton A, Smith P: Syndrome characterized by osteitis fibrosa disseminata, areas of pigmentation and endocrine dysfunction, with precocious puberty in females. Report of five cases. $N$ Engl J Med 1937, 216:727-746.

2. Weinstein LS, Shenker A, Gejman PV, Merino MJ, Friedman E, Spiegel AM: Activating mutations of the stimulatory $\mathrm{G}$ protein in the McCuneAlbright syndrome. N Engl J Med 1991, 325(24):1688-1695.

3. Scurry MT, Bicknell JM, Fajans SS: Polyostotic Fibrous Dysplasia And Acromegaly. Arch Intern Med 1964, 114:40-45.

4. Lumbroso S, Paris F, Sultan C: Activating Gsalpha mutations: analysis of 113 patients with signs of McCune-Albright syndrome-a European Collaborative Study. J Clin Endocrinol Metab 2004, 89(5):2107-2113.

5. Ehrig U, Wilson DR: Fibrous dysplasia of bone and primary hyperparathyroidism. Ann Intern Med 1972, 77(2):234-238.

6. Shenker A, Laue L, Kosugi S, Merendino J, Minegishi T, Cutler G: A constitutively activating mutation of the luteinizing hormone receptor in familial male precocious puberty. Nature 1993, 365(6447):652-654

7. Danon M, Crawford JD: The McCune-Albright syndrome. Ergeb Inn Med Kinderheilkd 1987, 55:81-115.

8. Bajpai A, Greenway A, Zacharin M: Platelet dysfunction and increased bleeding tendency in McCune-Albright syndrome. J Pediatr 2008, 153(2): 287-289.

9. Shenker A, Weinstein LS, Moran A, Pescovitz OH, Charest NJ, Boney CM, et al: Severe endocrine and nonendocrine manifestations of the McCuneAlbright syndrome associated with activating mutations of stimulatory $G$ protein GS. J Pediatr 1993, 123(4):509-518.

10. Roman R, Lopez P, Johnson MC, Boric MA, Gallo M, Ponce C, et al: Sudden infant death syndrome and activating GNAS1 gene mutations. Fetal Pediatr Pathol 2007, 26(4):199-205.

11. Volkl TM, Dorr HG: McCune-Albright syndrome: clinical picture and natural history in children and adolescents. J Pediatr Endocrinol Metab 2006, 19(Suppl 2):551-559.

12. Damian M, Mary S, Martin A, Pin JP, Baneres $\mathrm{J}$ : $G$ protein activation by the leukotriene B4 receptor dimer. Evidence for an absence of transactivation. J Biol Chem 2008, 283(30):21084-21092.

13. Garbarg M, Schwartz JC: Synergism between histamine H1- and H2receptors in the CAMP response in guinea pig brain slices: effects of phorbol esters and calcium. Mol Pharmacol 1988, 33(1):38-43.

14. Hasko G, Shanley TP, Egnaczyk G, Nemeth ZH, Salzman AL, Vizi ES, et al: Exogenous and endogenous catecholamines inhibit the production of macrophage inflammatory protein (MIP) 1 alpha via a beta adrenoceptor mediated mechanism. Br J Pharmacol 1998, 125(6):1297-1303.

15. Nakahari $T$, Ito $S$, Yoshida $H$, Furuya $E$, Imai Y: Accumulation of cAMP evoked by acetylcholine stimulation in rat submandibular acinar cells: observation of exocytosis, fluid secretion and [Ca2+]i. Exp Physiol 2000, 85(2):159-169.

16. Blinowski JT: [The role of catecholamines in vasomotor rhinitis]. Pneumonol Pol 1985, 53(10):487-491.

17. Liu J, Jiang EK, Chang ZJ: [The effect of substance $P$ on the content of CAMP in cultured cells of the rat anterior pituitary gland]. Zhongguo Ying Yong Sheng Li Xue Za Zhi 2003, 19(1):101-102.

18. Sullivan TJ, Parker KL, Eisen SA, Parker CW: Modulation of cyclic AMP in purified rat mast cells II. Studies on the relationship between intracellular cyclic AMP concentrations and histamine release. J Immunol 1975, 114(5):1480-1485.

19. Sullivan TJ, Parker KL, Stenson W, Parker CW: Modulation of cyclic AMP in purified rat mast cells. I. Responses to pharmacologic, metabolic, and physical stimuli. J Immunol 1975, 114(5):1473-1479.

20. Suh $\mathrm{BC}$, Lee $\mathrm{H}$, Lee IS, Kim KT: Modulation of $\mathrm{H} 2$ histamine receptormediated CAMP generation and granulocytic differentiation by extracellular nucleotides via activation of protein kinase C. J Leukoc Biol 2001, 69(1):169-176.

21. Gbahou F, Vincent L, Humbert-Claude M, Tardivel-Lacombe J, Chabret C, Arrang JM: Compared pharmacology of human histamine $\mathrm{H} 3$ and $\mathrm{H} 4$ receptors: structure-activity relationships of histamine derivatives. $\mathrm{Br} J$ Pharmacol 2006, 147(7):744-754.

22. Torrent A, Moreno-Delgado D, Gomez-Ramirez J, Rodriguez-Agudo D, Rodriguez-Caso C, Sanchez-Jimenez F, et al: H3 autoreceptors modulate histamine synthesis through calcium/calmodulin- and CAMP-dependent protein kinase pathways. Mol Pharmacol 2005, 67(1):195-203.

23. Chiosi E, Valente F, Naviglio S, Illiano G: "Cross talk" between proteinkinase $\mathrm{C}(\mathrm{PKC})$ and adenylate cyclase (AC) in human platelets. Ital J Biochem 1989, 38(6):407A-409A

24. Bjorgo E, Solheim SA, Abrahamsen H, Baillie GS, Brown KM, Berge T, et al: Cross talk between phosphatidylinositol 3-kinase and cyclic AMP (CAMP)-protein kinase a signaling pathways at the level of a protein kinase B/beta-arrestin/cAMP phosphodiesterase 4 complex. Mol Cell Biol 2010, 30(7):1660-1672

25. Carbajal L, Biswas A, Niswander LM, Prizant H, Hammes SR: GPCR/EGFR cross talk is conserved in gonadal and adrenal steroidogenesis but is uniquely regulated by matrix metalloproteinases 2 and 9 in the ovary. Mol Endocrinol 2011, 25(6):1055-1065

26. Dhanya NB, Rai $R$, Srinivas CR: Histamine 2 blocker potentiates the effects of histamine 1 blocker in suppressing histamine-induced wheal. Indian Dermatol Venereol Leprol 2008, 74(5):475-477.

27. Moniri $\mathrm{NH}$, Booth RG: Role of PKA and PKC in histamine $\mathrm{H} 1$ receptormediated activation of catecholamine neurotransmitter synthesis. Neurosci Lett 2006, 407(3):249-253.

28. Bakker RA, Casarosa P, Timmerman H, Smit MJ, Leurs R: Constitutively active $\mathrm{Gq} / 11$-coupled receptors enable signaling by co-expressed $\mathrm{G}(\mathrm{i} / \mathrm{o})$ coupled receptors. J Bio/ Chem 2004, 279(7):5152-5161.

29. Kalogeromitros D, Katsarou A, Armenaka M, Rigopoulos D, Zapanti M, Stratigos I: Influence of the menstrual cycle on skin-prick test reactions to histamine, morphine and allergen. Clin Exp Allergy 1995, 25(5):461-466

30. Kirmaz C, Yuksel H, Mete N, Bayrak P, Baytur YB: Is the menstrual cycle affecting the skin prick test reactivity? Asian Pac J Allergy Immunol 2004, 22(4):197-203.

31. Morton T, Ansari M, Jacobson J: Gender differences and hormonal modulation of $\mathrm{G}$ protein galpha $\mathrm{q} / 11$ expression in lymphoid organs. Neuroendocrinology 2003, 78:147-153.

32. Jacobson JD, Ansari MA, Kinealy M, Muthukrishnan V: Gender specific exacerbation of murine lupus by gonadotropin-releasing hormone: Potential role of G alpha q/11. Endocrinol. 1999, 140:3429-3437.

33. Marshall WA JMT: Puberty. In Human Growth. Edited by Falkner FTJ. New York: Plenum Press; 1986:171--210.

34. Zweiman B, Lavker RM, Presti C, Atkins PC: Comparisons of inflammatory responses in IgE-mediated and codeine-induced skin reactions. J Allergy Clin Immunol 1993, 91(4):963-965.

35. Sheen $\mathrm{CH}$, Schleimer RP, Kulka M: Codeine induces human mast cell chemokine and cytokine production: involvement of G-protein activation. Allergy 2007, 62(5):532-538.

36. Turkeltaub PC, Rastogi SC, Baer H, Anderson MC, Norman PS: A standardized quantitative skin-test assay of allergen potency and stability: studies on the allergen dose-response curve and effect of wheal, erythema, and patient selection on assay results. J Allergy Clin Immunol 1982, 70(5):343-352

37. Petersen $L$, Mosbech H, Skov PS: Allergen-induced histamine release in intact human skin in vivo assessed by skin microdialysis technique: characterization of factors influencing histamine releasability. J Allergy Clin Immunol 1996, 97(2):672-679.

38. Jauregui I, Ferrer M, Montoro J, Davila I, Bartra J, del Cuvillo A, et al: Antihistamines in the treatment of chronic urticaria. J Investig Allergol Clin Immunol 2007, 17(Suppl 2):41-52. 
39. Lee EE, Maibach HI: Treatment of urticaria. An evidence-based evaluation of antihistamines. Am J Clin Dermatol 2001, 2(1):27-32.

40. Lin RY, Curry A, Pesola GR, Knight RJ, Lee HS, Bakalchuk L, et al: Improved outcomes in patients with acute allergic syndromes who are treated with combined $\mathrm{H} 1$ and $\mathrm{H} 2$ antagonists. Ann Emerg Med 2000, 36(5):462468.

41. Fedorowicz Z, van Zuuren EJ, Hu N: Histamine H2-receptor antagonists for urticaria. Cochrane Database Syst Rev 2012, 3, CD008596.

42. Alman BA, Greel DA, Wolfe HJ: Activating mutations of Gs protein in monostotic fibrous lesions of bone. J Orthop Res 1996, 14(2):311-315.

43. Marie PJ, de Pollak C, Chanson P, Lomri A: Increased proliferation of osteoblastic cells expressing the activating Gs alpha mutation in monostotic and polyostotic fibrous dysplasia. Am J Pathol 1997, 150(3): 1059-1069.

44. Bianco P, Riminucci M, Majolagbe A, Kuznetsov SA, Collins MT, Mankani MH, et al: Mutations of the GNAS1 gene, stromal cell dysfunction, and osteomalacic changes in non-McCune-Albright fibrous dysplasia of bone. J Bone Miner Res 2000, 15(1):120-128.

doi:10.1186/1939-4551-6-9

Cite this article as: Jacobson et al:: Allergic manifestations and cutaneous histamine responses in patients with McCune Albright syndrome. World Allergy Organization Journal 2013 6:9.

\section{Submit your next manuscript to BioMed Central and take full advantage of:}

- Convenient online submission

- Thorough peer review

- No space constraints or color figure charges

- Immediate publication on acceptance

- Inclusion in PubMed, CAS, Scopus and Google Scholar

- Research which is freely available for redistribution 